\title{
BORDER SURVEILLANCE AND CONTROL SYSTEM, PERSPECTIVES FOR ITS ESTABLISHMENT AND PRACTICAL APPLICATION
}

\author{
Roberts Vikainis ${ }^{1}$, Inta Pokule ${ }^{2}$ \\ ${ }^{1}$ B.iur., Docent of Border Guard and Immigration Service Subjects Department of \\ the State Border Guard College, e-mail: roberts.vikainis@rs.gov.lv, Rēzekne, Latvia \\ ${ }^{2} \mathrm{Mg}$.paed., Lecturer of Border Guard and Immigration Service Subjects Department \\ of the State Border Guard College, e-mail: inta.pokule@rs.gov.lv, Rēzekne, Latvia
}

\begin{abstract}
Effective management of the European Union's external borders is a key priority and a condition for the proper implementation and maintenance of the Schengen area of free movement, which is one of the most important achievements of European integration. One of the cornerstones of effective management of the European Union's external borders is the timely, accurate and complete exchange of information between all the authorities responsible for controlling the European Union's external borders. The establishment of a European Border Surveillance System (EUROSUR) is an effective tool for such an exchange of information. Within the framework of the EUROSUR project implementation, Latvia has started work on the establishment of the Border Surveillance and Control System, which in the near future will become a basic tool in the development of the Latvian situation image with its further integration into the European situation image. The aim of the study is to study the EUROSUR implementation guidelines at the European Union level, to study the development and implementation of the Border Surveillance and Control System in the State Border Guard, to analyze its functionality and practical application possibilities, to study the existing problems in the Border Surveillance and Control System, and to evaluate.
\end{abstract}

Keywords: border, control system, development perspectives.

\section{Introduction}

Given the dramatic changes in the security environment around the world, the number of external and internal threats has risen sharply, and their identification and response planning pose new challenges. Geopolitical developments in the Middle East and North Africa: war, internal conflicts, civil wars and riots, the migration crisis in Europe and terrorist attacks have been major factors influencing the European Union's border security in recent years, putting significant pressure on illegal immigration at external borders and internal security.

Integrated management of the European Union's borders was developed through measures to strengthen the European Union's external borders and the internal security of the Member States. An efficient and comprehensive system of information exchange and cooperation between all authorities responsible for the control of the European Union's external 
borders plays an important role in ensuring its smooth and efficient functioning. It is the European Border Surveillance System (EUROSUR).

\section{Establishment and development of the European Border Surveillance System (EUROSUR)}

In the recommendations of the Communication from the Commission of the European Communities of 13 February 2008 entitled "Study on the establishment of a European Border Surveillance System (EUROSUR)" (COM (2008) 68 final), Member States bordering the European Union invited to set up:

- one National Focal Point, which continuously coordinates the activities of all national authorities carrying out external border control tasks (detection, identification, tracing and interception) and is able to exchange information with the National Focal Points of other Member States as well as the operational agencies of the European Agencies. management of cooperation at the external borders of the EU Member States (FRONTEX Agency);

- a single national surveillance system combining surveillance activities at all external borders or, on the basis of a risk analysis, in separate parts of them, and ensuring the continuous dissemination of information between all authorities involved in the control of the external borders (Communication from the Commission of the European Communities of 13 February 2008 entitled "Study on the establishment of a European Border Surveillance System (EUROSUR)" (COM (2008) 68 final) Recommendation 1, European Commission, 2008).

The main objective of the establishment of EUROSUR was defined as the need for a common technical framework to facilitate effective action by Member States' authorities at local level, governance at national level, coordination at European level and cooperation with third countries to detect, detect, trace and intercept to enter the EU by bypassing border crossings.

The next most important step in the establishment of EUROSUR was the adoption of the EUROSUR Regulation (REGULATION (EU) No 1052/2013 OF THE EUROPEAN PARLIAMENT AND OF THE COUNCIL of 22 October 2013 establishing a European Border Surveillance System (EUROSUR)).

This Regulation established a common framework for the exchange of information and cooperation between Member States and FRONTEX to improve situational awareness and response aft the external borders of the Member States in order to detect, prevent and combat illegal immigration and cross-border crime and to protect and save migrants' lives 
(REGULATION (EU) No 1052/2013 OF THE EUROPEAN PARLIAMENT AND OF THE COUNCIL of 22 October 2013 establishing a European Border Surveillance System (EUROSUR) Paragraph 1, European Parliament, 2013).

EUROSUR included the following components: national focal points, national situational pictures, communication network, European situational picture, common border intelligence picture and sharing of surveillance tools.

EUROSUR became operational at the end of 2013. The 18 member states of the Union located at the southern and eastern external borders, including Latvia and the Schengen associated country Norway, started operating there. The other Member States of the Union joined EUROSUR in the following years.

EUROSUR was based on the "National Focal Points", through which all national authorities responsible for border surveillance cooperated and coordinated. The exchange of information on incidents at land and sea external borders, as well as the exchange of analytical reports and data between them national authorities.

Such cooperation and exchange of information has enabled the Member State concerned to react much more quickly to incidents involving illegal migration and cross-border crime or the threat to migrants' lives.

However, it must be remembered that the success, efficiency and sustainability of any system is based on its flexibility, ability to adapt to changing situations, timely response to different levels of threats, vulnerabilities and continuous improvement, ensuring continuous maintenance and safe, secure and efficient operation.

The rapid changes in the geopolitical situation in recent years, the migration crisis, especially on the Western Balkans route in 2015 and 2016, and the terrorist attacks in Europe are the two main crisis situations that the European Union has had to deal with since the adoption of EUROSUR. Both crisis situations clearly demonstrated the need for an effective and comprehensive European system for the exchange of information and cooperation between border and coast guards. EUROSUR should be improved in this respect (Report from the Commission to the European Parliament and the Council of 12 September 2018 (COM (2018) 632 final) point 2.2.0., European Commission, 2018).

REGULATION (EU) 2019/1896 OF THE EUROPEAN PARLIAMENT AND OF THE COUNCIL of 13 November 2019 on European Border and Coast Guard and repealing Regulations (EU) No 1052/2013 and (EU) 2016/1624 (hereinafter - FRONTEX Regulation).

This Regulation establishes EUROSUR, an integrated framework for the exchange of information and operational cooperation in European Border and Coast Guard, in order to improve situational awareness and response 
capacity for border management, including the detection, prevention and fight against illegal immigration and cross-border crime and the protection of migrants' lives. Rescue (REGULATION (EU) 2019/1896 OF THE EUROPEAN PARLIAMENT AND OF THE COUNCIL of 13 November 2019 on European Border and Coast Guard and repealing Regulations (EU) No 1052/2013 and (EU) 2016/1624 - Article 18, European Parliament, 2019).

EUROSUR shall be used for border checks at authorized border crossing points and for external land, sea and air border surveillance, including the monitoring, detection, identification, tracing, prevention and interception of unauthorized border crossings in order to detect, prevent and combat illegal immigration and cross-border crime. (REGULATION (EU) 2019/1896 OF THE EUROPEAN PARLIAMENT AND OF THE COUNCIL of 13 November 2019 on European Border and Coast Guard and repealing Regulations (EU) No 1052/2013 and (EU) 2016/1624 - Article 19, European Parliament, 2019).

Member States and the Agency shall use EUROSUR for the exchange of information and cooperation in border control, taking into account existing information exchange and cooperation mechanisms. EUROSUR consists of the following components: (REGULATION (EU) 2019/1896 OF THE EUROPEAN PARLIAMENT AND OF THE COUNCIL of 13 November 2019 on European Border and Coast Guard and repealing Regulations (EU) No 1052/2013 and (EU) 2016/1624 - Article 20, European Parliament, 2019).

- National Focal Points - Coordinate and exchange information between all authorities responsible for external border control at national level, as well as with other National Focal Points and FRONTEX, and maintain and operate this center;

- National situational picture - Each national focal point shall establish and maintain a national situational picture in order to provide effective, accurate and timely information to all authorities responsible for external border control at national level;

- European situational picture - FRONTEX establishes and maintains a European situational picture to provide national coordination centers and the Commission with efficient, accurate and timely information and analysis covering external borders, border areas and unauthorized secondary movements;

- Specific situational awareness - FRONTEX and Member States may establish and maintain specific situational awareness in support of specific operational activities at the external borders or for the exchange of information with Union institutions, bodies, offices and agencies, international organizations or with third countries;

- EUROSUR merger services - FRONTEX coordinates EUROSUR merger services in order to provide national coordination centers, the Commission 
and itself with information on external borders and the border area on a regular, reliable and cost-effective basis;

- Integrated planning - FRONTEX develops an integrated planning process for border management and returns, including operational planning, contingency planning and capacity building planning.

\section{Implementation of the European Border Surveillance System (EUROSUR) in Latvia}

Evaluating the conditions for the implementation of EUROSUR, it can be concluded that for the successful implementation of EUROSUR in Latvia, it is necessary to implement three basic tasks:

- Establishment of the EUROSUR National Coordination Center;

- creation of a national system that will ensure the functioning of the image of the state situation;

- integration of the national situation picture into the EUROSUR system.

In accordance with the Cabinet of Ministers Order No. 696 of 1 December 2010 "On Determining the Institution Responsible for the Implementation of the European Border Surveillance System (EUROSUR)", the Ministry of the Interior has been designated as the institution responsible for implementing EUROSUR at the national level.

The implementation of EUROSUR in Latvia is carried out by the State Border Guard in cooperation with the Ministry of the Interior, the Ministry of Defense, the National Armed Forces, the Ministry of Finance and the Ministry of Transport. (Order No. 696 of the Cabinet of Ministers of 1 December 2010 "On Determining the Responsible Institution in the Implementation of the European Border Surveillance System (EUROSUR)", Cabinet of Ministers of the Republic of Latvia, 2010 ).

In order to ensure gradual, sequential and consistent implementation of EUROSUR, the State Border Guard developed a EUROSUR implementation plan, which was approved by the Cabinet of Ministers. Taking into account the development trends of the EUROSUR project at the Union level, the EUROSUR implementation plan is regularly updated, which ensures the effective implementation of the EUROSUR implementation process in Latvia.

Based on the approved EUROSUR implementation plans, the State Border Guard prepared and implements 7 EUROSUR implementation project activities in Latvia, which significantly bring EUROSUR implementation closer, with the involvement of competent authorities in shaping the European situation and strengthening the Union's external border. (Order No. 651 of the Cabinet of Ministers of 18 December 2019 
"On the Integrated Management Plan of the State Border of the Republic of Latvia 2019-2020. - point 5, Cabinet of Ministers of the Republic of Latvia, 2019)

In accordance with the State Border Law of the Republic of Latvia, the functions of the EUROSUR National Coordination Center are performed by the State Border Guard (Law on the State Border of the Republic of Latvia Section 9.2.). In order to ensure the successful performance of these functions, a National Coordination Center was established within the Operational Management Department of the State Border Guard, operating twenty-four hours a day, seven days a week and coordinating activities within EUROSUR and joint activities with competent national authorities National focal points.

(Regulations No. 32 of the State Border Guard of 27 December 2017 "Regulations of the State Border Guard" - Paragraph 31, State Border Guard, 2017).

\section{Establishment and development of the Latvian Border Surveillance and Control System}

In order to ensure a high-quality and accurate image of the national situation with its further integration into EUROSUR, in 2015 the State Border Guard started the development of the Border Surveillance and Control System.

The border surveillance and control system is designed as open source software, which consists of several modules and allows you to upgrade the added modules or add new modules as needed.

It is planned to include the following modules in the Border Surveillance and Control System for visualization of the operational and tactical situation, display of the operation of technical means, personnel:

- $\quad$ Geographic data processing module - provides:

- display of high-quality and complete geospatial data on the electronic geographical map, incl. Representation of the objects of the State Border Guard and co-operation institutions on the map, ensuring the necessary detail;

- display of the Global Positioning System (GPS) data function from Motorola radios (in case of resource movement, providing line display on the map);

- creation of an interface for the transmission and processing of GPS data from the tactical communication devices, personal communication devices and sensors at the disposal of the State Border Guard (in case of movement of resources, ensuring the display of the line on the map); 
- $\quad$ creation of an address search function (find coordinates by address and find the nearest address to be determined by coordinates);

- $\quad$ creation of an event information input form and display of events on the map, following the EUROSUR designations;

- $\quad$ use of card data and event data from both central and local servers, ensuring continuity of availability of card service materials and information;

- $\quad$ search, filter and map data of historical events;

- Requesting, processing and displaying resource and event data for the Border Guard Information System (RAIS).

- personnel module - ensures the maintenance of up-to-date information on the personnel of the relevant structural unit of the State Border Guard, its availability, absence, possibility to involve in the performance of service duties within the specified period of time;

- technical module - ensures maintenance of up-to-date information on technical means available in the relevant State Border Guard structural unit and involved in border control measures (video surveillance systems, presence detection systems, means of communication, etc.), sending and visualizing GPS data on electronic geographical map and displaying received information in BCS;

- Geopositioning system module of the Information Center of the Ministry of the Interior - provides display of GPS data from Motorola walkie-talkies and from tactical communication devices, personal communication devices and sensors at the disposal of the State Border Guard;

- Incident Generation Module - provides input of information on events and incidents and their display on the electronic geographical map, following the EUROSUR designations;

- module for creation of assignments and control of their operation ensures planning of tasks of border guard assignments and control of the process of execution of the given tasks, route of movement of border guard assignments to the electronic geographical map;

- Tactical situation display module - provides display of the tactical situation in the border surveillance section of a separate structural unit of the State Border Guard on an electronic geographical map (logging works, agricultural work, hunting, etc.), display of the movement route of border guard assignments, etc :;

- fixed cartographic plan module - provides display of fixed cartographic data on the electronic geographical map (marking of the state border, location of boundary markers, location of landmarks, various objects, etc.) 
The border surveillance and control system includes and visualizes information on events related to the control of the country's external border and the situation within the country. Transparency and systematisation of information The Border Surveillance and Control System uses several groups of information in accordance with the EUROSUR information systematisation standards.

In order to ensure data protection, Regulation (EU) 2016/679 of the EUROPEAN PARLIAMENT AND OF THE COUNCIL of 27 April 2016 on the protection of individuals with regard to the processing of personal data and on the free movement of such data and repealing Directive 95/46 / EC ( General Data Protection Regulation) the information entered in the Border Surveillance and Control System is granted the status of classified information according to the "EU RESTRICTED" standard.

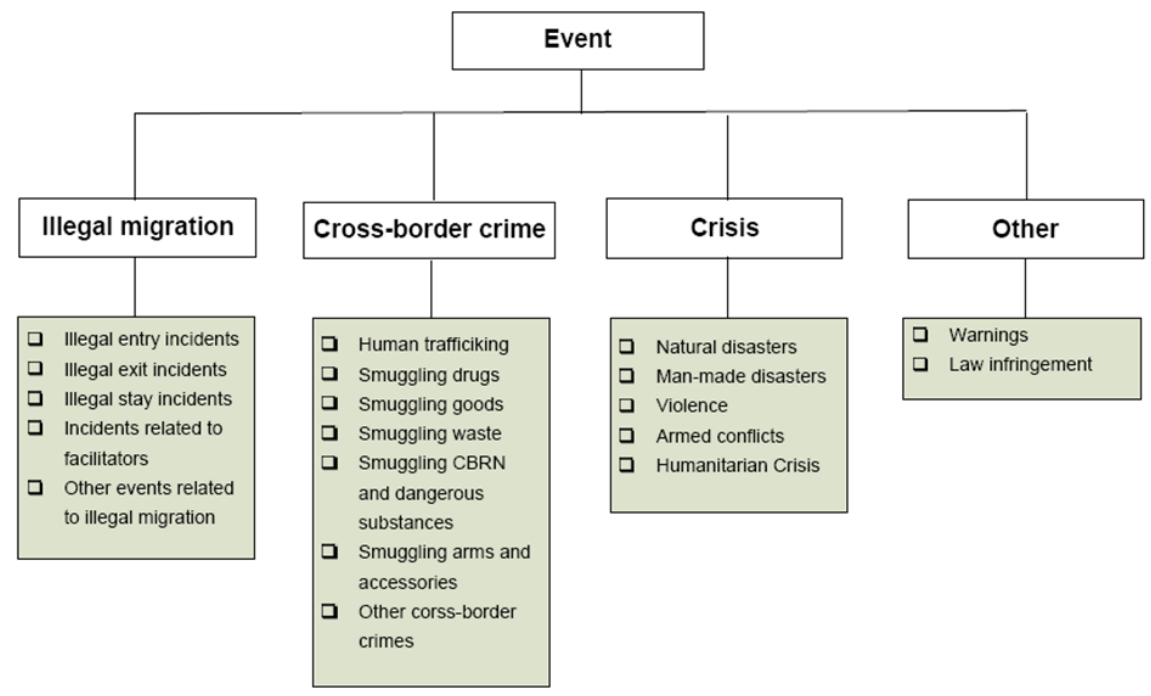

Figure 1. Grouping of information to be included in the border surveillance and control system (SBG unpublished materials, 2018)

The border surveillance and control system is structured in 3 hierarchical levels:

- 1.National level - National Coordination Center of the State Border Guard (NCC);

- 2.Regional level - Operational Management Divisions of the Territorial Administration of the State Border Guard (RCC); 
- 3.Local level - Border Guard Divisions of the Territorial Board of the State Border Guard (LCC).

Each of these levels of the hierarchy is granted strictly differentiated access rights for the use and administration of the Border Surveillance and Control System. Each user is entitled to perform only those activities and access only the amount of information determined according to his / her status in the Border Surveillance and Control System:

- Border Guard Division of the Territorial Administration of the State Border Guard (LKC) - provides input and visualization of Incidents / Events, operation of border guard assignments, operation of technical means, etc. detected in the border guard section of the Border Guard Division of the Territorial Administration of the State Border Guard;

- Operational Management Divisions of the Territorial Administration of the State Border Guard (RCC) - ensures timely exchange of information and timely cooperation between the structural units of the Territorial Administration of the respective State Border Guard, controls the activities of the relevant territorial units of the Border Guard and immigration control, etc.;

- National Border Guard Coordination Center (NCC) - ensures timely exchange of information and timely cooperation between all national authorities responsible for external border control at national level, as well as with other national coordination centers and FRONTEX, ensures timely exchange of information at national level with search and rescue, law enforcement, asylum and immigration authorities and manages the dissemination of relevant information, assists in the efficient and effective management of resources and personnel, supports the coordination, planning and implementation of national border control activities, develops and maintains national situational awareness, coordinates operational activities, etc.

\section{Challenges in the implementation of the Latvian Border Surveillance and Control System}

In accordance with the EUROSUR implementation plans, the transmission of EUROSUR information to the FRONTEX Situation Center using the unified National Border Guard National Coordination Center is planned to be completed in 2026. As mentioned above, in order to achieve this goal, the State Border Guard started work on the development and implementation of the Border Surveillance and Control System. Currently, part of the measures envisaged in the EUROSUR implementation plan has already been implemented - the National Coordination Center of the State Border Guard has been established, which operates 24/7 and exchanges 
information with the National Coordination Centers of other European Union Member States, as well as the creation and maintenance of the National Situation Picture, measures have been initiated to combine the border surveillance and control components of the unified information exchange and processing platform by building the Border Surveillance and Control System, which already has an integrated land border video surveillance system, as well as the geo-positioning of the resources of the State Border Guard has been ensured, work has begun on an interministerial agreement on the procedure for information exchange and cooperation within EUROSUR between the State Border Guard and other institutions involved in ensuring state border security.

The following measures are necessary for the successful implementation of the EUROSUR implementation plan:

- to ensure the establishment of the infrastructure of video surveillance, monitoring and control systems of the land border of the State Border Guard;

- to link the necessary national supervisory and control information exchange systems to EUROSUR, ensuring full use of the information provided by the relevant systems of the Information Center of the Ministry of the Interior, the Ministry of Defense, the National Armed Forces, the Ministry of Finance and the Ministry of Transport;

- to increase the speed of information flow in the internal communication network of the Ministry of the Interior in the structural units of the State Border Guard, to ensure the correct operation of the modules of the Border Surveillance and Control System;

- to ensure the transmission of EUROSUR information to the FRONTEX Situation Center through the joint National Coordination Center of the State Border Guard, certification of the Border Surveillance and Control System and the attached information source, structural units of the State Border Guard and co-responsible authorities and compliance with EU RESTRICTED standards.

\section{Conclusions and suggestions}

In view of the above, the authors of the study conclude that the Border Surveillance and Control System:

- will serve as an effective tool for planning, organizing and coordinating border surveillance measures, promoting the use of appropriate resources and personnel to ensure an effective, intensive and uniform level of border control at the external borders of the Republic of Latvia; 
- will ensure timely input and visualization of information on the digital map about the situation and detected events at the external border of the Republic of Latvia, operation of border guard assignments, operation of technical means, etc. activities at the Local, Regional and National levels;

- will ensure rapid and full exchange of information between the State Border Guard and other institutions involved in the implementation of state border security measures of the Republic of Latvia (for example, subordinate institutions of the Ministry of the Interior, Ministry of Defense, National Armed Forces, Ministry of Finance, Ministry of Transport, etc.);

- after integration into EUROSUR, will ensure the creation and maintenance of Latvia's national situational picture in EUROSUR, promoting timely exchange of information and timely cooperation between the authorities of the European Union Member States responsible for external border control, as well as other national coordination centers and FRONTEX.

\section{References}

1. Cabinet of Ministers Order No. 651 of 18 December 2019 "On the Republic of Latvia the State Border Integrated Management Plan 2019-2020. year'.

2. Cabinet of Ministers Order No. 696 of 1 December 2010 "On Institutions Responsible implementation of the European Border Surveillance System (EUROSUR) ".

3. Communication from the Commission of the European Communities of 13 February 2008 entitled Surveillance System (EUROSUR) "(COM (2008) 68 final).

4. REGULATION (EU) 2016/399 OF THE EUROPEAN PARLIAMENT AND OF THE COUNCIL of 9 March 2016 on the Union Code on the rules governing the movement of persons over borders (Schengen Borders Code).

5. REGULATION (EU) 2016/679 OF THE EUROPEAN PARLIAMENT AND OF THE COUNCIL of 27 April 2016 on the protection of individuals with regard to the processing of personal data and on the free movement of such data and repealing Directive 95/46 / EC (General Data Protection Regulation).

6. REGULATION (EU) 2019/1896 OF THE EUROPEAN PARLIAMENT AND OF THE COUNCIL 13 November 2006 on European Border and Coast Guard and repealing Regulation (EU) No 1052/2013 and (EU) 2016/1624.

7. REGULATION (EU) No 1052/2013 OF THE EUROPEAN PARLIAMENT AND OF THE COUNCIL of 22 December 2013 establishing a European Border Surveillance System (EUROSUR) (not applicable).

8. Regulation No. 32 of the State Border Guard of 27 December 2017 "State Border Guard regulations".

9. Report from the Commission of the European Communities to the European Parliament and the Council of 12 September 2018. To the Council (COM (2018) 632 final).

10. State Border Law of the Republic of Latvia.

11. Unpublished materials of the Ministry of the Interior of the Republic of Latvia.

12. Unpublished materials of the State Border Guard. 